\title{
都市空間における移動経路のパターンと流動量に 関する積分幾何学的考察
}

\section{ANALYSIS OF THE PATTERNS OF PATHS AND THE QUANTITY OF FLOWS IN URBAN SPACE USING INTEGRAL GEOMETRY}

\author{
及川清昭* \\ Kiyoaki OIKA WA
}

\begin{abstract}
The objective of this study is to propose new geometrical methods for analyzing the probability distribution of paths and the quantity of flows in urban space. Regarding a path as a segment which links origin to destination, the middle points of paths are supposed randomly distributed in a two dimensional area. According to the patterns of paths intersecting a convex or circular area and the probability distribution of the length of paths, the equations for measuring the the quantity of flows are obtained using the theory of integral geometry. Proposed methods are tested by examining the traffic volume in Tokyo.
\end{abstract}

\section{Keywords: Patterns of Paths, Quantity of Flows, Integral Geometry, Random Distribution, Intrazonal Trips, Traffic Volume 経路パターン，流動量，積分幾何学，ランダム分布，内内交通，交通量}

\section{1.はじめに}

本研究の目的は，都市空間における人や車の移動現象 を計量的に分析するために、新たな幾何学的モデルを提 案し、移動経路の長さ・パターンと領域内の流動量に関 して数理的な理論化をはかることにある。

従来から移動・交通現象を対象とした研究は数多くな されているが、そのなかのテーマのひとつとして、ゾー ン内内交通量やゾーン間の内外交通量の計量的把握が試 みられている。これらの研究の多くは、居住地の面積や 人口密度、移動目的、就業者数、産業構造など、考えら れうる要因を抽出し、OD調査などの結果をもとに、それ らのパラメータを用いて交通量の推計・予測を行うとい うものである（例えば松浦[1987 $]^{1)}$ など）。人や車の移動 現象には複雑な要因が絡み合っているため、現象をモデ ル化する際にも、様々な条件を加味せざるを得ないこと は確かである。しかし、多くのパラメー夕を抽出して定 式化をはかると、どれが本質的な要因になっているのか、
また、それぞれの要因がどのように関連するのか、判断 が難しい面がある。さらに、パラーメータの值が地域に よって異なると一層把握しにくくなり、地域間の比較も 容易ではない。むしろ、パラメー夕を限定し、単純化を はかったほうが、現象を理解しやすいことも多い。

幾何学的な観点からすると、内内、内外といった経路 パターン別の交通量は対象とする領域の大きさに依存す る。直観的にも理解されるように、対象領域が大きいほ ぞ内内交通量の割合が増加し、極端に大きな領域を設定 すると、ほとんどが内内交通のみとなる。一方、通過交 通についてみると、領域が小さくなるほど割合が増加し てゆく。本論では、この点に着目してみる。すなわち、 移動現象に関与する要因を領域の大きさと移動経路の長 さのみに限定し、経路パターンと流動量に関する数理的 性質を捉えてみる。例えば、領域が大きくなると内内 ・ 内外・通過交通量（トリップ数）の比率はどのように変 化するのか、また、それぞれの流動量（トリップの総延

\footnotetext{
* 東京大学生産技術研究所 助手. 工博
}

Research Assoc., Institute of Industrial Science University of Tokyo, Dr. Eng. 


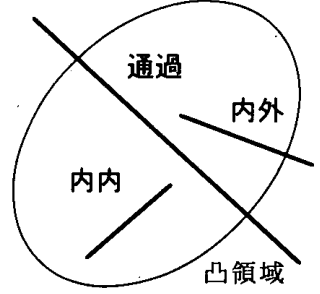

図1.凸領域と経路パターン

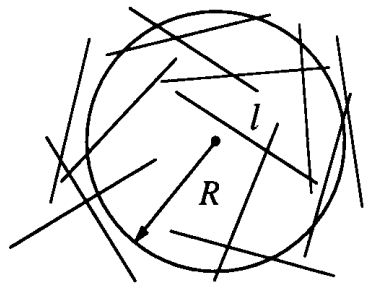

図2. 経路長が一定
長）はどのような值を示すか、といった移動現象を理解 する上での基本的な量の把握を試みる。その際、現実の 事象から計量モデルを構成するのではなく、幾何学的な モデルを演繹的に構築し、現象がそのモデルからどれだ け乘離しているかを分析するというアプローチをとる。 ここで、理論化のための前提条件を次のように設定する。 $<1>$ 移動経路(1) は起点と終点を結ぶ線分と仮定する。

$<2>$ 移動経路(線分)の中点は平面上において連続的に分 布するものとし、中点の位置・線分の方向ともに、 一様ランダムに分布するものとする。

<3> 経路が交わる領域の形態は凸領域とし、特に円の場 合を主たる対象とする。

<4> 凸領域あるいは円と経路との交わり方を、経路の端 点の位置に基づいて、「内内」·「内外」·「通過」 という3つのパターンに分類する（図1）。

いうまでもなく、人や車の移動現象は鉄道や道路など のネットワーク上で展開されており、また、経路の発 生・集中密度も場所によって異なっている。これに対し て、ここで提案する幾何学的モデルは、“平面上におい てランダムに分布する線分と凸領域(円)との交わり”が基 本となっており、ランダムな移動現象をきわめて単純化 したモデルである。ネットワークが比較的均質かつ密に 分布していること、また、経路の発生・集中密度が一様 であることが措定されている。したがって、モデルの適 用にも限界があるが、流動量の分布を大局的に把握し、 現実の移動現象と比較できる基本的な計量モデルとする には、ネットワークを直接扱うよりも、連続平面で理論 展開をはかるほうが適していることがある。実際、連続

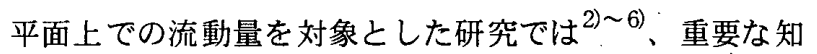
見がいくつか見いだされている。また、本論でも論及す るように、連続平面を対象とした流動量をネットワーク 上の流動量に対応づけることも可能となる。

以下、本論では具体的に次の事項について議論する。

[1] 領域の大きさとパターン別トリップ数の比率との関 連を明らかにするために、円と交わる一様ランダム な経路のパターン別生起確率を導出する (2章)。

[2] 領域内での流動量を計量するために、凸領域と交わ る経路の長さの期待值を導出する。また、ネットワ 一ク上の断面流動量との数理的連関(3章)、および、 経路パターン別の流動量について定式化する(4章)。

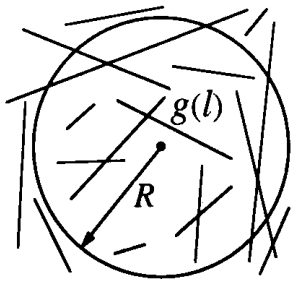

図3． 経路長が確率分布

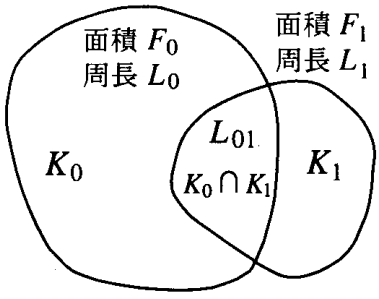

図4. 凸領域の交わり
[3] 導出した理論を車両のOD調査（東京都23区）に適 用し、方法の検討と事例分析を行う( 5 章)。

理論化に際しては、経路の長さ（以下、単に「経路 長」と呼ぶ）を一定とした場合（図2）と、ある確率密度 分布にしたがって分布する場合（図3 ; 記号の添字として Wを付す) とに分け、「積分幾何学(幾何確率)」の理論を 援用しながら定式化する。なお、積分幾何学に関する理 論については、Santalo[1976] ${ }^{7)}$ やそれを都市解析の分 野に導入している腰塚 $[1976]{ }^{8)}$ 等を参照している。

\section{2. 経路パターン別の生起確率}

図1で示した 3 つの経路パターンの生起確率は、経路長 と領域の形態・大きさに依存する。ここでは、簡単のた めに領域の形態を円とし、ランダムな線分が円と交わる ときに（図2）、内内・内外・通過のどのパターンになる か、という生起確率を定式化してみる。

\section{1 経路長を一定とした場合}

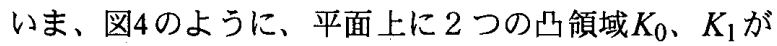
あり、それぞれの面積を $F_{0} 、 F_{1}$ 、周長を $L_{0} 、 L_{1}$ とする。 また、 $K_{0}$ が固定され、 $K_{1}$ が動くものとする。 $K_{1}$ の運動学 的密度を $d K_{1}$ とすると、 $K_{1}$ が $K_{0} に$ 交わる全測度はBlaschke による積分幾何の主公式 ${ }^{7)} ら$ 、

$$
\int_{K_{0} \cap K_{1} \neq \phi} d K_{1}=2 \pi\left(F_{0}+F_{1}\right)+L_{0} L_{1}
$$

と与えられる。ここで、凸領域 $K_{0}$ を半径 $R$ の円とみすと、 $F_{0}=\pi R^{2} 、 L_{0}=2 \pi R$ であり、一方、 $K_{1}$ を長さlの線分とす ると、 $F_{1}=0 、 L_{1}=2 l$ であるから、上式は、

$$
\int_{K_{0} \cap K_{1} \neq \phi} d K_{1}=2 \pi R(\pi R+2 l)
$$

となる。つまり、線分が円と交わる ${ }^{(2)}$ 全測度が上式で表さ れることになる。

次に、経路パターン別の測度を求めてみる。線分が円 の内部に含まれる測度を $M_{0} 、 1$ 点で交わる測度を $M_{1} 、 2$ 点で交わる測度を $M_{2}$ とする。それぞれ、内内、内外、通 過という3つの経路パターンに相当している。線分が円 と交わる全測度が(2)式で表されるから、明らかに、

$$
M_{0}+M_{1}+M_{2}=2 \pi R(\pi R+2 l)
$$

が成立している。積分幾何学においては、合同な図形の 


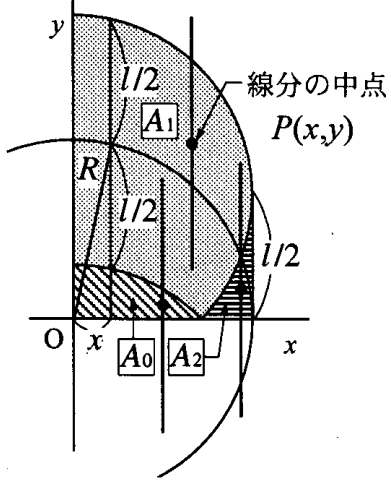

(1) $0<l \leqq 2 R$

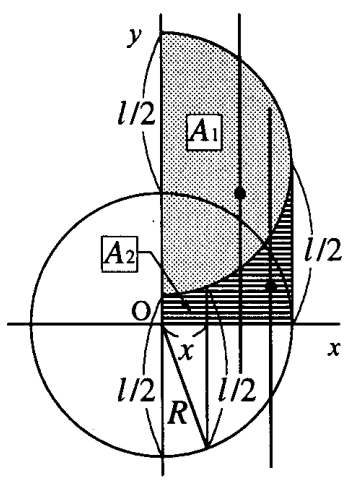

(2) $l>2 R$
図5.線分の位置の測度(1)
図6.線分の位置の測度(2)
集合の測度は、図形上に定められた点 $P(x, y)$ と、その図形

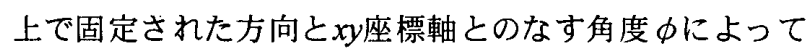

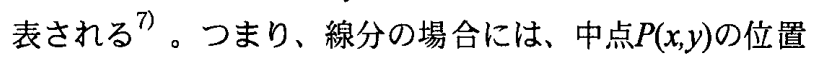
と座標軸とのなす角度 $\phi$ で計量できる。例えば、面積 $A$ の 領域内部に中点をもち、かつ、あらゆる方向に分布して いる線分の集合の測度は、 $2 \pi A$ となる。したがって、経 路パターン別の測度 $M_{i}(i=0,1,2)$ は、円と交わる線分の中 点 $P(x, y)$ が占める面積 $A_{i}$ を求め、それに $2 \pi$ を乗ずればよ い。すなわち、 $M_{i}$ の定式化は以下のようになる（面積 $A_{i}$ の領域を同じく $A_{i}$ と表記する）。

$$
M_{i}=\int_{P \in A_{i}} \int_{0 \leqq \phi<2 \pi} d x d y d \phi=2 \pi A_{i}
$$

それぞれの面積 $A_{i}$ は、図5、図6に示すように図形から直 接求めることができる(両図とも、線分の方向を $y$ 軸方向に 固定した場合で、円の 1 / 4のみ（第 1 象限）を図示； $\sum_{i=0}^{i=2} A_{i}=R(\pi R+2 l)$ となっていることに注意）。

よって、図2のように長さの線分が平面上にランダム に分布するとき、パターン別の生起確率 $P_{i}$ は、(4)式を(3) 式で除すことによって、次のように導かれる。

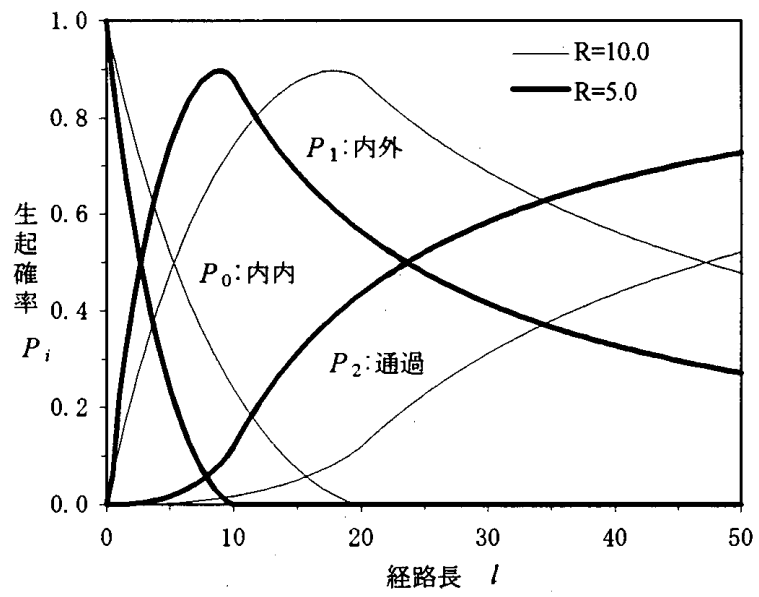

図7. 経路長と生起確率

$$
P_{i}=A_{i} / R(\pi R+2 l) \quad(i=0,1,2)
$$

表1には経路パターン別に、中心点の占める面積 $A_{i}$ およ び生起確率 $P_{i}$ の導出結果をまとめて示している ${ }^{(3)}$ 。

図7は半径 $R$ を固定したとき（図では $R=5, R=10$ の $2 つ の$ 場合を例示）、経路長lと生起確率 $P_{i}$ の関係を、表 1 の諸式 を用いて図化したものである。経路が長くなるほど（半 径が小さいほど）内内経路の生起確率が著しく減少し、 通過経路の確率が増大するという変化が計量的に明らか にされている。また、内外経路の生起確率は、極大值を もつことがわかる。

\section{2 経路長が確率分布にしたがう場合}

\section{（1）経路パターン別の定式化}

図7から理解されるように、パターン別生起確率 $P_{i}$ は経 路の長さによって大きく左右される。そこで、次に、現 実の移動現象を想定し、経路長がある確率分布にしたが って分布する場合について展開してみる。

いま、経路長が確率密度関数 $\mathrm{g}($ ()にしたがって、その中 点が平面上に一様ランダムに分布しているものとする (図3参照 ; $g($ ( は円と交わる確率ではないことに注意)。

\begin{tabular}{|c|c|}
\hline (1) $0<l \leqq 2 R$ のとき & (2) $l>2 R$ とき \\
\hline 面積 $A_{i}$ & $* q=\left(4 R^{2}-x^{2}\right)^{1 / 2} / 2$ \\
\hline [内内 $A_{0}=4 \int_{0}^{q}\left[\left(R^{2}-x^{2}\right)^{1 / 2}-l / 2\right] d x$ & $A_{0}=0$ \\
\hline [内外] $A_{1}=4 \int_{0}^{q} l d x+4 \int_{q}^{R} 2\left(R^{2}-x^{2}\right)^{1 / 2} d x$ & $A_{1}=4 \int_{0}^{R} 2\left(R^{2}-x^{2}\right){ }^{1 / 2} d x$ \\
\hline [通過］ $A_{2}=4 \int_{q}^{R}\left[l / 2-\left(R^{2}-x^{2}\right)^{1 / 2}\right] d x$ & $A_{2}=4 \int_{0}^{R}\left[l / 2-\left(R^{2}-x^{2}\right)^{1 / 2}\right] d x$ \\
\hline 確率 $P_{i} \quad\left[P_{i}=A_{i} / R(\pi R+2 l)\right]$ & $※ \alpha=\left(4 R^{2}-l^{2}\right)^{1 / 2} / 2$ \\
\hline [内内 $] P_{0}=\left[2 R^{2} \cos ^{-1}(l / 2 R)-l \alpha\right] / R(\pi R+2 l)$ & $P_{0}=0$ \\
\hline [内外] $P_{1}=\left[2 \pi R^{2}+2 l \alpha-4 R^{2} \cos ^{-1}(l / 2 R)\right] / R(\pi R+2 l)$ & $P_{1}=2 \pi R /(\pi R+2 l)$ \\
\hline [通過] $P_{2}=\left[2 R^{2} \cos ^{-1}(l / 2 R)-l \alpha+2 l R-\pi R^{2}\right] / R(\pi R+2 l)$ & $P_{2}=(2 l-\pi R) /(\pi R+2 l)$ \\
\hline
\end{tabular}

表1. 線分の中心点が占める面積 $A_{i}$ と経路パターン別の生起確率 $P_{i}$ 
経路長の期待値を $\mu$ とすると、経路が半径Rの円と交わる 全測度 $M_{\mathrm{W}}$ は、先の(3)式に $g(l)$ を乗じて積分し、

$$
M_{\mathrm{W}}=\int_{0}^{\infty} 2 \pi R(\pi R+2 l) g(l) d l
$$

と表される。ここで、期待值と確率密度関数の定義から、

$$
\int_{0}^{\infty} \lg (l) d l=\mu \quad \text { および } \quad \int_{0}^{\infty} g(l) d l=1
$$

であるから、(6)式は次のように簡単な式で表される。

$$
M_{\mathrm{W}}=2 \pi R(\pi R+2 \mu)
$$

つまり、経路長がある確率密度関数にしたがって分布し ている場合、円と交わる全測度は、その関数の形態には 依存せず、経路長の期待值のみで決定づけられる。とこ ろが、経路パターン別の測度 $M_{\mathrm{W} i}(i=0,1,2)$ については、

$$
M_{\mathrm{W} i}=2 \pi \int_{0}^{\infty} A_{i} g(l) d l
$$

となり、これは、表1に示した $A_{i}$ の諸式からもわかるよう に、確率密度関数 $g(l)$ の形態に依存し、期待値のみで定式 化することはできない。このときのそれぞれのパターン 別生起確率 $P_{\mathrm{W} i}\left(=M_{\mathrm{W} i} / M_{\mathrm{W}}\right)$ は次式のように表される ${ }^{(4)}$ 。

$$
P_{\mathrm{w} i}=\int_{0}^{\infty} A_{i} g(l) d l / R(\pi R+2 \mu)
$$

これが、一般のランダムな移動現象を扱う際の基本式と なるものであるが、残念ながら、この積分は陽に解けな い場合が多い。例えば、 $g(l) か ゙ 1$ 次関数の場合は解けるが、 多くは数値積分に依らざるを得ない。

\section{(2)経路長の確率分布とパターン別生起確率}

経路長の確率分布を実際の交通センサス(車両)の結果 ${ }^{9)}$ から求めた例を図8に示す。図に示した 8 点が調查結果か

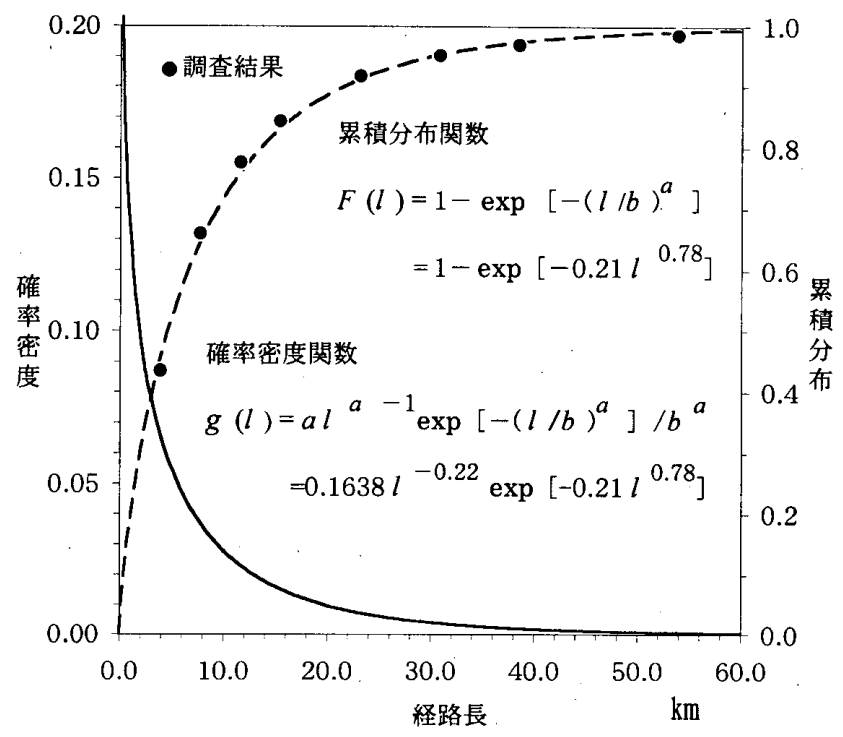

図8. 経路長の確率関数

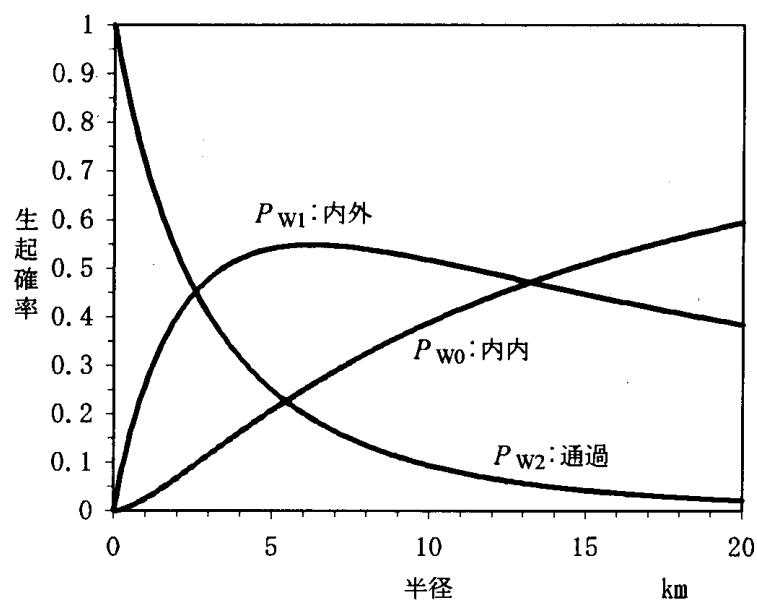

図9. 半径と経路パターン別生起確率

らの累積頻度分布である (東京都平日の例。道路距離は直線 距離の1.3倍として換算 ${ }^{10)}$ ) 。いま、この確率分布に適合す る関数としてワイブル分布をあてはめてみる。ワイブル 分布の確率密度関数は次式で与えられる。

$$
g(l)=a l^{a-1} \exp \left[-(l / b)^{a}\right] / b^{a}
$$

ここで、交通センサスの集計結果から、経路長の期待值 を $\mu=8.5(\mathrm{~km}$; 直線距離) とし、また、それぞれのパラメ 一夕は、図示した 8 点のデータをもとに、最小二乗法に よって、 $a=0.78 、 b=7.40$ と設定する。図8に示した曲線が、 推定したワイブル分布の確率密度関数 $g(l)$ と累積分布関数 $F(l)$ である(5)。

(10)式のワイブル分布をあてはめた場合、経路パターン 別生起確率 $P_{\mathrm{W} i}$ を先の $(9)$ 式と表 $1 の A_{i}$ の諸式から数值積分 によって求めると、図9のような結果を得る。この図から、 半径（領域の面積）が大きくなるほど内内経路の生起確 率が高くなり、通過経路の確率が著しく減少してゆく傾 向が把握できる。一方、内外経路の生起確率は単調な変 化ではなく、極大值を持つことがわかる。この結果を用 いた詳細な分析は5章で行うが、車両の移動経路（正確に は経路の中心とその方向）がランダムに分布すると仮定 した場合、半径にして約 $2.5 \mathrm{~km}$ 以内の都市領域では通過・ 内外・内内経路の順に比率が大きく、約 $5.5 \mathrm{~km}$ 以上になる と通過経路が最も少なくなることがわかる。また、半径 約 $13 \mathrm{~km}$ を境にして、最も比率が大きいのが内外経路から 内内経路に変わるといった䝨向も読みとることができる。

\section{3. 経路の数・長さと流動量の期待値}

前章では経路パターンという円と経路の交わり方の形 態的側面について理論化を試みたが、次に、経路の数 ・ 長さといった量的な側面に焦点をあて、領域内に含まれ る線分の長さ、すなわち流動量の期待值を求めてみる。 また、連続平面上の流動量とネットワーク上の断面流動 量との数理的連関について考察してみる。 


\section{1 凸領域内に含まれる線分の長さの期待值 (1)経路長を一定とした場合}

まず、凸領域と交わるランダムな線分の長さの期待值 を求めてみる。先に示した図4において、凸領域 $K_{0}$ と $K_{1}$ の 交わり部分 $\left(K_{0} \cap K_{1}\right)$ の境界の長さを $L_{01}$ とすると、次式が 成り立つことが知られている7)。

$$
\int_{K_{0} \cap K_{1} \neq \phi} L_{01} d K_{1}=2 \pi\left(F_{0} L_{1}+F_{1} L_{0}\right)
$$

ここで、 $K_{1}$ を長さlの線分とし、線分が領域 $K_{0}$ と交わる長 さを $s$ とる（図10）。線分の場合、周長 $L_{1}=2 l$ 、面積 $F_{1}$ $=0$ であり、また、境界の長さ $L_{01}=2 s$ となるので、上式は 次のように表される。

$$
\int_{K_{0} \cap K_{1} \neq \phi} s d K_{1}=2 \pi F_{0} l
$$

一方、 $K_{\mathrm{l}}$ が $K_{0} に$ 交わる全測度はすでに(1)式で示したが、 $K_{1}$ が線分の場合、 $F_{1}=0 、 L_{1}=2 l$ を(1)式に代入すると、

$$
\int_{K_{0} \cap K_{1} \neq \phi} d K_{1}=2\left(\pi F_{0}+l L_{0}\right)
$$

となる。よって、凸領域に含まれる線分の長さの期待値 を $E(S)$ とすると、(12)式を(13)式で除して、

$$
E(S)=\pi F_{0} l /\left(\pi F_{0}+l L_{0}\right)
$$

と定式化される。直観的にもわかることであるが、この 式から、領域の面積 $F_{0}$ が大きくなるほど、期待值 $E(s)$ の値 はlに漸近してゆくことが明らかになる。

\section{（2）経路長が確率分布にしたがう場合}

次に、線分の長さが確率密度関数 $g(l)$ にしだって分布 する場合について展開してみる。このとき、内部に含ま れる線分の集合の測度は、(12)式から、

$$
\int_{0}^{\infty} 2 \pi F_{0} l g(l) d l=2 \pi \mu F_{0}
$$

と求められる。また、線分が $K_{0}$ と交わるときの全測度は、 (13)式を用いて、次式のように導かれる。

$$
\int_{0}^{\infty} 2\left(\pi F_{0}+l L_{0}\right) g(l) d l=2\left(\pi F_{0}+\mu L_{0}\right)
$$

よって、期待値を $E_{\mathrm{W}}(s)$ とすると(15)式を(16) 式で除して、

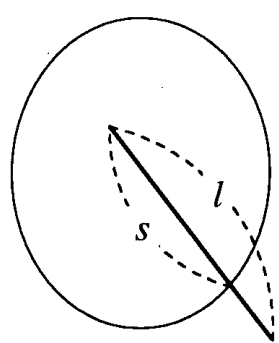

図10.凸領域と交わる線分の長さ

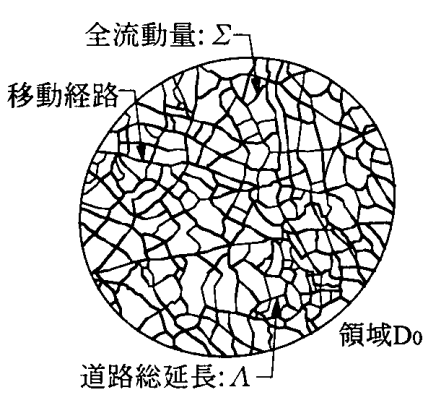

総延長: 1

図11.衤ワークと経路の長さ

$$
E_{\mathrm{W}}(s)=\pi \mu F_{0} /\left(\pi F_{0}+\mu L_{0}\right)
$$

と求められる ${ }^{(6)}$ 。つまり、経路の中点が一様ランダムに分 布するという仮定のもとでは、凸領域内部に含まれる経 路の長さの期待值は、その確率分布 $g(l)$ の形態によらず、 経路長の平均值 $\mu$ のみ゙決定づけられることがわかる。 なお、経路長lが一定の場合の(14)式に対し、単にlを平均 值

\section{2 ネットワーク上の断面流動量との関連}

ここで、前項で導いた凸領域内部に含まれる経路の長 さ（凸領域内部の流動量）の期待值と、ネットワーク上 の断面流動量との数理的連関について定式化しておく。

いま、平面上に領域 $D_{0}$ を設定し、 $D_{0}$ 内における移動経 路の長さ（単位時間当たり）の総和を $\Sigma$ とする(図 11$) 。$ $\Sigma$ の值が一般にいう流動量である。同じ $D_{0}$ 内に総延長 $\Lambda$ の道路ネットワークがあるとき、道路上の断面流動量の 期待値 $\eta$ は、

$$
\eta=\Sigma / \Lambda
$$

であるから、クは $\Lambda$ $\Sigma$ から推定可能となる。

ここで、領域と交わる経路の総数をNとすると、(17)式 は 1 本の線分あたりの期待值を表しているので、領域内

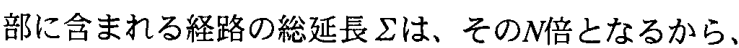

$$
\Sigma=N E_{\mathrm{W}}(s)
$$

となる。よって、断面流動量の期待値 $\eta$ は、(17)〜(19)式 から次式のように表される。

$$
\eta=\pi \mu F_{0} N / \Lambda\left(\pi F_{0}+\mu L_{0}\right)
$$

このように、移動経路がランダムに分布している場合、 道路ネットワーク上の断面流動量の期待値は、領域の面 積・周長、経路の数、経路長の平均値、道路の総延長に よって表わされる。

経路の総数Nについては、実際は捉えにくい量であるが、

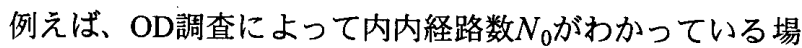
合は、領域を円とみなし、(9)式で表される内内経路の生 起確率 $P_{\mathrm{W} 0}$ を用いて、

$$
N=N_{0} / P_{\text {WO}_{0}}
$$

と求めることができる。したがって、(20)、(21)式を用い れば車両の断面交通量を推計できることになる

\section{4. 経路パターンと流動量の関連}

前章では領域内に含まれる経路の長さ、すなわち内部 流動量の期待值を導出したが、この章では、経路パター ン別にみた流動量の期待值について理論化を試みる。

\section{1 経路長を一定とした場合}

長さ 1 のンダムな線分が半径Rの円と交わるとき、円 に含まれる長さの期待值を $E_{\mathrm{C}}(s)$ とすると、(14)式に円の 


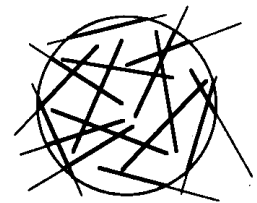

内部流動量の期待值: $E \mathrm{c}(S)$

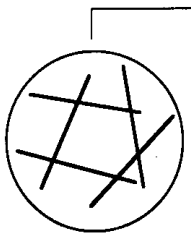

内内: $P_{0} \xi 0$

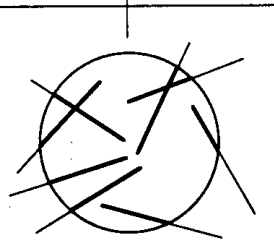

内外: $P 1 \xi 1$

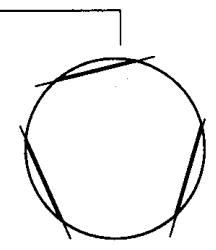

通過: $P 2 \xi 2$
図12.経路パターン別流動量の期待值

面積 $\left(F_{0}=\pi R^{2}\right)$ と周長（ $L_{0}=2 \pi R ）$ をあてはめて、

$$
E_{\mathrm{C}}(s)=\pi l R /(\pi R+2 l)
$$

となる。実は、この值は内内・内外・通過の 3 つの経路 パターンの条件付期待値が合成されたものとなっている ことがわかる（図12）。すなわち、次式が成立している。

$$
E_{\mathrm{C}}(s)=P_{0} \xi_{0}+P_{1} \xi_{1}+P_{2} \xi_{2}
$$

ここに、 $\xi_{i}(i=0,1,2)$ は、経路パターンが既知のときの条 件付期待值を表す。例えば、 $\xi_{1}$ は全事象を内外経路に限 ったとき、円の内部に含まれる経路長の期待值である。 また、 $P_{i}$ は先に表1で示した経路パターン別の生起確率で ある。 $P_{i} \xi_{i}$ の值が、いうならば、全体の期待値 $E_{\mathrm{C}}(s)$ に対 する配分量を表しているといえる。

ここで、それぞれの $P_{i} \xi$ iについて定式化してみる。ま ず、内内経路については、線分が円に完全に含まれるか ら、明らかに、 $\xi_{0}=l$ である。つまり、

$$
P_{0} \xi_{0}=P_{0} l
$$

となる。また、通過経路の条件付期待值 $\xi_{2}$ は、先に示し た図5、図6から解析的に求めることができる。両図にお いて、中心が原点Oから犺ある線分が円に含まれる長さ は、 $2\left(\mathrm{R}^{2}-x^{2}\right)^{1 / 2}$ であるから、領域 $A_{2}$ を囲む曲線

$$
l / 2-\left(R^{2}-x^{2}\right)^{1 / 2}
$$

を用いて、次式のように求めることができる。

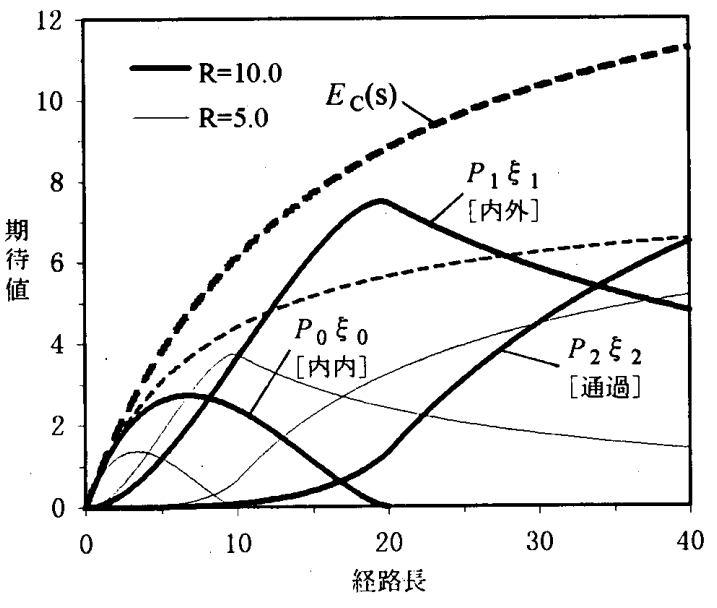

図13. 円と交わる経路長の期待值（経路長一定）

$$
\begin{aligned}
\xi_{2}=\int_{t}^{R} 8 & {\left[l / 2-\left(R^{2}-x^{2}\right)^{1 / 2}\right]\left(R^{2}-x^{2}\right)^{1 / 2} d x / A_{2} } \\
\text { (1) } t & \left.=\left[R^{2}-(l / 2)^{2}\right)\right]^{1 / 2} \quad(0<l \leqq 2 \mathrm{R} ; \text { 図5) } \\
\text { (2) } t & =0
\end{aligned}
$$

また、先に示した(5)式より、 $P_{2}=A_{2} / R(\pi R+2 l)$ であ るから、 $P_{2} \xi_{2}$ はこれらの積分を解けばよい。

一方、内外経路については、全体の期待值 $E_{\mathrm{C}}(S)$ が(22) 式から既知なので、 $E_{\mathrm{C}}(S)$ から $P_{0} \xi_{0}$ および $P_{2} \xi_{2}$ を減ずれ ばよい。以上の手続きによって得られた $P_{i} \xi_{i}$ の導出結果 を表2に一覧して示す。

図13は経路長lと流動量の経路パターン別配分量 $P_{i} \xi_{i}$ の 値、およびその和、すなわち全体の期待值 $E_{\mathrm{C}}(s)$ との関係 を図化したものである（半径 $R=5$ と $R=10$ の $2 \supset$ の場合を 例示）。経路長が円の直径よりも小さいときは、内内・ 内外経路が全体の期待値のほとんどを占めているが、経 路長が增加にするにつれてつれて、通過経路の割合が增 大する傾向が見てとれる。

\section{2 経路長が確率分布にしたがう場合}

経路長が平均 $\mu て ゙ 、$ 確率密度分布 $g(l)$ にしたがって平 面上に分布しているとき、円の内部に含まれる経路の長 さの期待值 $E_{\mathrm{W}}(s)$ とすると、(17)式の $F_{0} 、 L_{0}$ に円の面積と 周長をそれぞれあてはめて、

$$
E_{\mathrm{W}}(S)=\pi \mu R /(\pi R+2 \mu)
$$

と求められる。半径が大きくなるほど、 $E_{\mathrm{W}}(s)$ は平均值 $\mu$

表2. 流動量の経路パターン別配分量 $P_{i} \xi_{i}$

\section{(1) $0<l \leqq 2 R$ のとき}

[内内] $P_{0} \xi_{0}=l\left[2 R^{2} \cos ^{-1}(l / 2 R)-l \alpha\right] / R(\pi R+2 l)$

[内外] $P_{1} \xi_{1}=\left[16 R^{3} / 3+2 l^{2} \alpha-8 \alpha R^{2}+8 \alpha^{3} / 3\right] / R(\pi R+2 l)$

[通過] $P_{2} \xi_{2}=\left[\pi l R^{2}-16 R^{3} / 3-l^{2} \alpha+8 \alpha R^{2}-8 \alpha^{3} / 3\right.$

$$
\left.-2 l R^{2} \cos ^{-1}(l / 2 R)\right] / R(\pi R+2 l)
$$

(2) $l>2 R$ とき

$$
\begin{aligned}
& P_{0} \xi_{0}=0 \\
& P_{1} \xi_{1}=16 R^{2} / 3(\pi R+2 l) \\
& P_{2} \xi_{2}=R(\pi l-16 R / 3) /(\pi R+2 l) \\
& \circledast \alpha=\left(4 R^{2}-l^{2}\right)^{1 / 2} / 2
\end{aligned}
$$




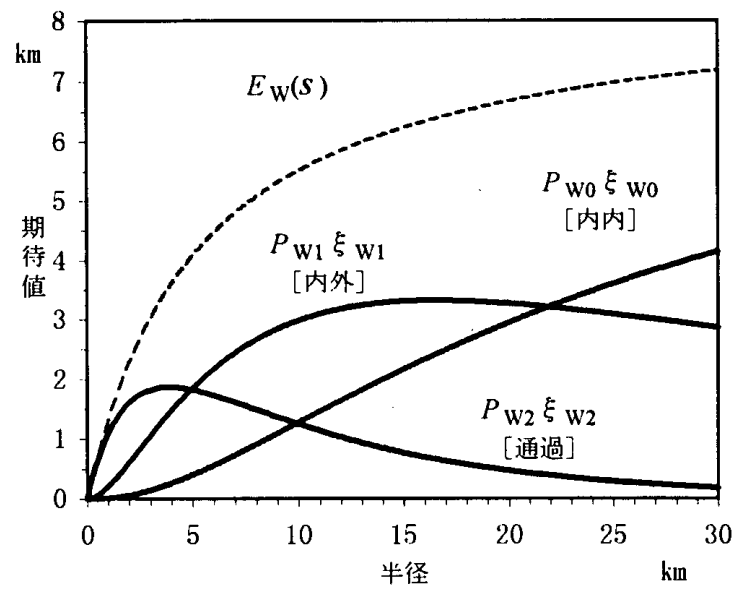

図14. 円と交わる経路長の期待値（ワイブル分布）

に漸近する。一方、経路パターン別の配分量 $P_{\mathrm{W} i} \xi_{\mathrm{W} i}$ につ いて定式化してみると、経路の中心点が占める領域の面 積 $A_{i}$ (表1参照)を用いて、次のように表すことができる。

$$
P_{\mathrm{W} i} \xi_{\mathrm{W} i}=2 \pi \int_{0}^{\infty} g(l) A_{i} \xi_{i} d l / M_{\mathrm{W}}
$$

ここで、線分が半径 $R$ の円と交わる全測度 $M_{\mathrm{W}}$ は、既に2 章 の(7)式で与えられており、また $A_{i}$ と $P_{i}$ は(5)式で表される 関係にあるから、上式は、

$$
P_{\mathrm{W} i} \xi_{\mathrm{W} i}=\int_{0}^{\infty} g(l) P_{i} \xi_{i}(\pi R+l) d l /(\pi R+2 \mu)
$$

と表すことができ、これは表 2 $P_{i} \xi_{i}$ を用いて積分を解

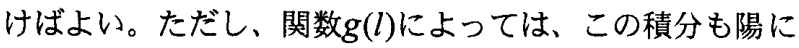
解けないことが多く、数值積分を用いざるを得ない。

経路長の確率分布としてワイブル分布(図 8 ; 車両の移 動現象)をあてはめた場合、(27)式で表わされるパターン 別の期待值を図示すると、図14のようになる。この図か ら、経路がランダムに分布している場合、半径にして約 5 km以下の都市領域では通過交通による流動量が多いこと がわかる。例えば、半径 $3 \mathrm{~km}$ の場合（次章で示すが、東京 都の行政区は半径にして2〜 $5 \mathrm{~km}$ 程度である）、円に含ま

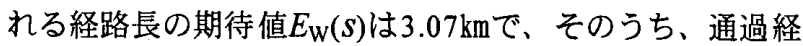
路の配分量 $\left(P_{\mathrm{W}_{2}} \xi_{\mathrm{w}_{2}}\right)$ は $1.68 \mathrm{~km}$ である。つまり、領域内の 交通量は過半が通過交通で占められていることになる。 また、半径が $5 \mathrm{~km} \sim 10 \mathrm{~km}$ 程度では内外交通による流動量が 支配的で、一方、内内交通による流動量は、領域が大き くなるにつれて増加するものの、半径 $10 \mathrm{~km}$ 以下の都市領 域の場合、全体の流動量に対して占める割合は非常に少 ないことがわかる。

\section{5. 理論の適用方法と事例分析}

これまでの導出結果の適用事例として、東京都23区に おける車両のOD調査の結果 ${ }^{11)}$ をとりあげ、各行政区ご とに、経路パターン別生起確率 [(9)式] の検証を試みる。

\section{1 対象領域の形態}

本論で導出した理論式は対象領域を主に円と設定して いるので、適用に際しては、まず、行政区の形状が円に 対応づけられるかどうかという問題がある。一般に、行 政区の形状は非凸であるから、何らかの図形処理を施さ なければならない。ここでは、領域の凸包を求め、凸包 と面積が等しい円（以下「等価円」と呼び、その半径を 「等価半径」と呼ぶ）との対応を検討してみる ${ }^{(8)}$ 。

最初に、図15のように各行政区の凸包を求め、ランダ ムシミュレーションを行ってみた。すなわち、平面上に ランダムに線分を発生させ、凸包と交わる線分がどのパ ターンになるか、その確率を計量してみた。線分の長さ

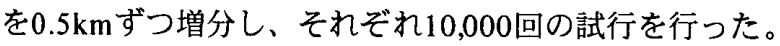
図16はその結果の一例である。図示した曲線が等価円の 理論値 $P_{i}$ (表 1 参照) であり、点でプロットした値がシミ ユレーションの平均值である。凸包は多角形であるから、 全般的に、等価円に比して通過経路となる確率が幾分大 きくなることは認められたが、各区ごとに平均誤差(線分 の長さあたりの理論値との誤差の平均)を求めてみると、 最大で 0.0011 、最小が 0.0002 となり、いずれの区におい ても理論值との誤差は極めて小さいことが実証された。 すなわち、凸包における経路パターン別生起確率は、等 価円の理論式によく近似できることが明らかになった ${ }^{(9)}$ 。

\section{2 内内経路数と内外経路数の比率による分析}

行政区の凸包が等価円に対応づけられる見通しが得ら れたので、次に、本論で導出した経路パターン別の生起 確率の適用方法について検討する。

OD調查の結果を分析する際、例えば、内内経路数の比 率が大きいほど、内部での結びつきが高いと判断できる。 しかし、これを地域間相互に比較する場合には、単純に その比率のみでは評価できない。なぜなら、繰り返し主 張しているように、面積の大きい地域ほど内内経路数の 比率が大きくなるからである。つまり、内内経路数の比 率を指標とするためには、領域の面積を考慮した基準値 が必要となり、その基準値のひとつとして、本論で導出 した経路パターン別の生起確率 $P_{\mathrm{W}}$ が考えられる。そこで、 各行政区ごとに、等価円に対して経路がランダムに分布

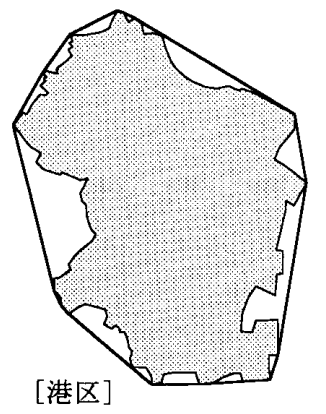

図15. 領域の凸包

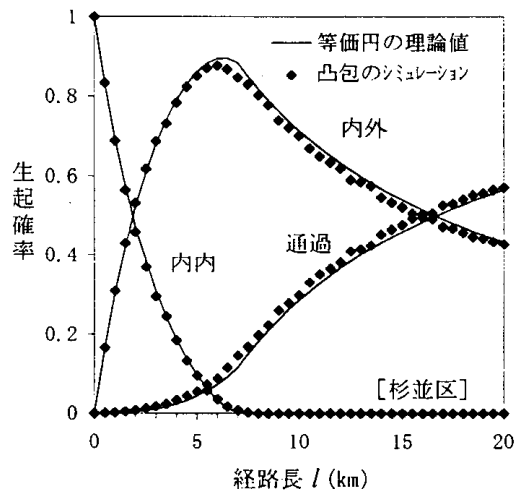

図16，理論値との適合性 
表3. 23区における計量結果

\begin{tabular}{|c|c|c|c|c|c|c|c|c|c|c|c|c|c|}
\hline & 区 名 & 実面積 & 凸 & & 等価 & & 交通調査 & & & & 等価円 & & 内内経路 \\
\hline & & 面積 & 面積 & 周長 & 半径 & 経路 & & 内内 & & 生起確桑 & & 内内 & 集中率 \\
\hline & & $\left(\mathrm{km}^{\prime}\right)$ & $\left(\mathrm{kn}^{3}\right)$ & (km) & (km) & 内内 & 内外 & 比率 & 内内 & 内外 & 通過 & 比率 & \\
\hline & & $S$ & $S_{n}$ & $L_{h}$ & $R_{\mathrm{E}}$ & $N_{0}$ & $N$ & $\rho_{\mathrm{E}}$ & $P_{\text {พั }}$ & $P_{w l}$ & $P_{W 2}$ & $\rho_{\mathrm{C}}$ & $\psi$ \\
\hline 1 & 千代田 & 11.64 & 13.37 & 13.83 & 2.06 & 148603 & 520667 & 0.222 & 0.071 & 0.410 & 0.519 & 0.148 & 1.495 \\
\hline 2 & 中 央 & 10.15 & 11.92 & 13.69 & 1.95 & 140019 & 520598 & 0.212 & 0.066 & 0.398 & 0.536 & 0.142 & 1.489 \\
\hline 3 & 港 & 20.22 & 24.61 & 18.65 & 2.80 & 272303 & 622119 & 0.304 & 0.107 & 0.469 & 0.424 & 0.185 & 1.642 \\
\hline 4 & 新 宿 & 18.25 & 25.67 & 19.75 & 2.86 & 179937 & 454214 & 0.284 & 0.110 & 0.473 & 0.417 & 0.188 & 1.508 \\
\hline 5 & 文 京 & 11.31 & 13.56 & 14.03 & 2.08 & 47788 & 223613 & 0.176 & 0.072 & 0.411 & 0.517 & 0.149 & 1.180 \\
\hline 6 & 台＼cjkstart東 & 10.08 & 12.09 & 13.69 & 1.96 & 130028 & 317105 & 0.291 & 0.067 & 0.399 & 0.534 & 0.143 & 2.032 \\
\hline 7 & 畦＼cjkstart田 & 13.75 & 17.09 & 16.77 & 2.33 & 69899 & 249256 & 0.219 & 0.084 & 0.435 & 0.481 & 0.162 & 1.348 \\
\hline 8 & 江＼cjkstart東 & 39.02 & 57.20 & 29.80 & 4.27 & 147041 & 331433 & 0.307 & 0.176 & 0.530 & 0.294 & 0.250 & 1.232 \\
\hline 9 & 品 川 & 22.71 & 30.14 & 20.69 & 3.10 & 87488 & 295567 & 0.228 & 0.121 & 0.487 & 0.392 & 0.199 & 1.146 \\
\hline 10 & 目＼cjkstart黒 & 14.71 & 23.70 & 18.77 & 2.75 & 44706 & 213846 & 0.173 & 0.104 & 0.466 & 0.430 & 0.183 & 0.946 \\
\hline 11 & 大 $⿴ 囗 十$ & 55.93 & 76.74 & 34.91 & 4.94 & 210313 & 371086 & 0.362 & 0.207 & 0.542 & 0.251 & 0.276 & 1.312 \\
\hline 12 & 世田谷 & 58.08 & 74.69 & 33.21 & 4.88 & 189379 & 403334 & 0.320 & 0.204 & 0.541 & 0.255 & 0.273 & 1.169 \\
\hline 13 & 啮 谷 & 15.08 & 18.76 & 17.13 & 2.44 & 94790 & 362122 & 0.207 & 0.090 & 0.444 & 0.467 & 0.168 & 1.235 \\
\hline 14 & 中 野 & 15.58 & 24.62 & 19.68 & 2.80 & 46777 & 183905 & 0.203 & 0.107 . & 0.469 & 0.424 & 0.185 & 1.094 \\
\hline 15 & 杉 並 & 34.03 & 39.46 & 23.08 & 3.54 & 93491 & 250348 & 0.272 & 0.142 & 0.507 & 0.350 & 0.219 & 1.240 \\
\hline 16 & 豊＼cjkstart島 & 13.00 & 17.45 & 16.38 & 2.36 & 69091 & 239542 & 0.224 & 0.085 & 0.437 & 0.478 & 0.164 & 1.368 \\
\hline 17 & 北 & 20.57 & 30.73 & 22.68 & 3.13 & 69386 & 195464 & 0.262 & 0.123 & 0.488 & 0.389 & 0.201 & 1.305 \\
\hline 18 & 荒 川 & 10.20 & 14.10 & 14.95 & 2.12 & 28831 & 140046 & 0.171 & 0.074 & 0.415 & 0.511 & 0.151 & 1.128 \\
\hline 19 & 板＼cjkstart橋 & 32.16 & 41.94 & 24.95 & 3.65 & 115636 & 308293 & 0.273 & 0.148 & 0.511 & 0.341 & 0.224 & 1.218 \\
\hline 20 & 練＼cjkstart馬 & 48.17 & 61.44 & 30.02 & 4.42 & 110584 & 300295 & 0.269 & 0.183 & 0.533 & 0.283 & 0.256 & 1.052 \\
\hline 21 & 足 立 & 53.14 & 70.63 & 31.01 & 4.74 & 189229 & 344224 & 0.355 & 0.198 & 0.539 & 0.263 & 0.268 & 1.323 \\
\hline 22 & 葛＼cjkstart飾 & 34.85 & 47.84 & 26.21 & 3.90 & 87660 & 244878 & 0.264 & 0.159 & 0.520 & 0.320 & 0.235 & 1.124 \\
\hline 23 & 江戸川 & 49.73 & 66.23 & 31.94 & 4.59 & 171097 & 286368 & 0.374 & 0.191 & 0.537 & 0.272 & 0.262 & 1.426 \\
\hline & $23 区$ & 617.38 & 757.90 & 101.68 & 15.53 & 5601962 & 1662551 & 0.771 & 0.522 & 0.440 & 0.038 & 0.542 & 1.422 \\
\hline
\end{tabular}

するときの理論値 $P_{\mathrm{w} i}$ と、OD調査の値との比較を試みる。 まず、OD調査では通過経路数は把握し得ないので、こ れを除外して指標化してみる。いま、調査結果による内 内経路数と内外経路数をそれぞれ、 $N_{0} 、 N_{1}$ とすると、

$$
\rho_{\mathrm{E}}=N_{0} /\left(N_{0}+N_{1}\right)
$$

で表される $\rho_{\mathrm{E}}$ 「内内比率」と呼び(10)、また、等価円に おける内内比率を $\rho_{\mathrm{C}}$ とし、同様に、

$$
\rho_{\mathrm{C}}=P_{\mathrm{W} 0} /\left(P_{\mathrm{w} 0}+P_{\mathrm{w} 1}\right)
$$

で表す。このとき両者の比を「内内経路集中率」と呼び、

$$
\psi=\rho_{\mathrm{E}} / \rho_{\mathrm{C}}
$$

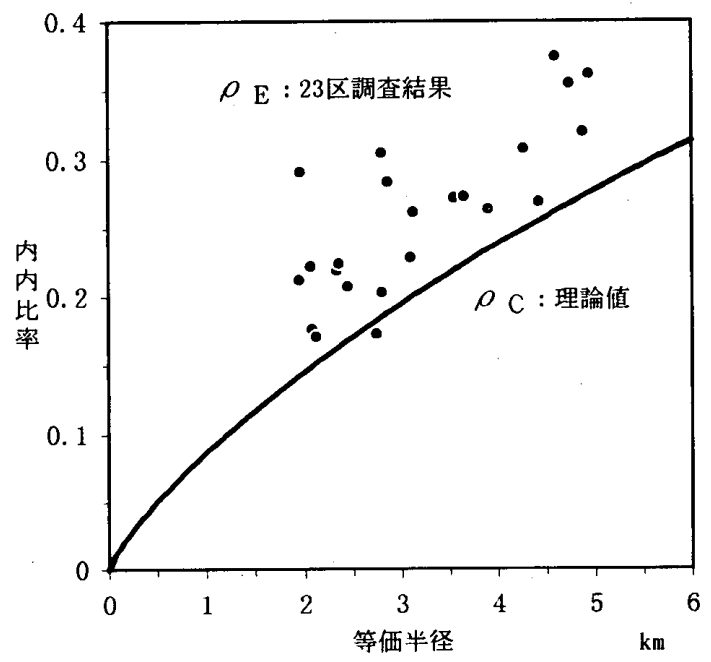

図17.内内比率
で定義する。内内経路集中率 $\psi$ はランダムな移動現象か らの乘離の度合いを表す指標でもあり、 $\psi$ の值が大きい ほど地域内での結びつきが高いことを示している。

図17の曲線は半径の変化に伴う内内比率の理論值 $\rho_{\mathrm{C}}$ を 図化したものであり、また、各点は行政区の内内比率 $\rho_{\mathrm{E}}$ の値（表3）をプロットしたものである。なお、経路長の 確率分布には2章で示したワイブル分布 [(10)式;図8］を あてはめて生起確率 $P_{\mathrm{W} i}[(9)$ 式] を求めている(1)。この図 をみると、等価円の理論值 $\rho_{\mathrm{C}}$ は半径にほぼ比例して増大 することがわかる。各行政区においても、面積が大きい ほど内内比率 $\rho_{\mathrm{E}}$ が増加する傾向を大まかには見てとれる が、地域的な差異もみられる。最も特徴的なのは、ほと

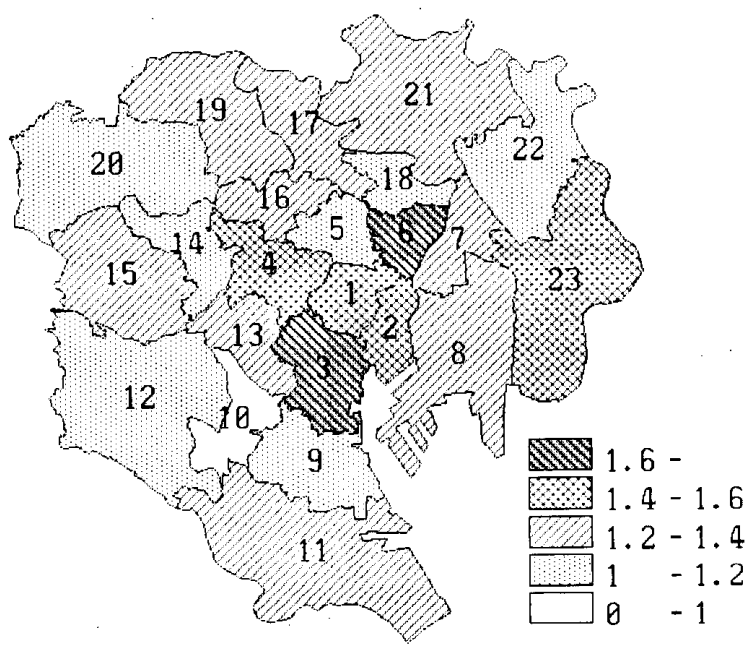

図18.内内経路集中率 
んどの行政区において内内経路集中率 $\psi$ が1を超えている ことである(表3)。つまり、一部の行政区を除くと、ラン ダムな場合と比較して、経路が自区内に集中しており、 内部での結びつきが高いことがわかる。

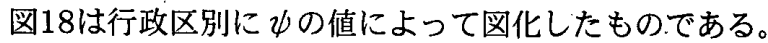
千代田・中央・港の都心3区は内内経路集中率の卓越性が 顕著であり、また、新宿・豊島の副都心地区や江戸川 ・ 墨田区も高くなっており、都心部ほど内内経路集中率が 高いことがわかる。また、台東区が特化しており、自区 内での移動が極端に多いことが注目される。

\section{6. おわりに}

本論では移動経路を起終点を結ぶ一本の線分とみなし、 線分の中点と方向がランダムに分布するモデルを提案し、 積分幾何学の知見を援用しながら理論化を試みた。理論 化の内容と分析結果を以下に簡単にまとめておく。

(1)円と交わる経路のパターン別（内内・内外・通過）生 起確率を導出し [表1の諸式と(9)式]、それぞれの経路の 割合が領域の大きさ（半径）によってどのように変化 するかについて明らかにした。

(2)凸領域内および円に含まれる経路長（流動量）の期待 值を定式化し $[(14) \cdot(17) \cdot(22) \cdot(27)$ 式]、流動量と領域 の大きさとの数理的連関を明示した。特に、経路長が 確率分布にしたがう場合、流動量は確率分布の形態に 依存せず、経路長の平均值のみで決定されることを示 した。また、経路パターン別の流動量を導出し[表2の 諸式と(27)式]、それぞれの流動量とその配分量が領域 （円）の大きさによってどのように変化するかについ ての計量的特性を明らかにした。

(3)連続平面上の流動量とネットワーク上の断面流動量と の関連を定式化し [(20)式]、OD調査による内内(ある いは内外)経路数をもとに、道路上の断面交通量の期待 值が推計可能 [(20)・(21)式] であることを示した。

(4)導出した理論值と、東京都 23 区における車両の $O D$ 調査 結果を比較し（笽密にはワイブル分布の適合性を検証 する必要があるが）、おしなべて、ランダムな移動現 象と比較して内内経路の割合が大きいことを実証した。 本論で提案した移動現象の幾何学的モデルは、あくま でも理論モデルにすぎないが、経路パターン別生起確率 や領域内部流動量の期待值は移動現象を把握するための 基本的な量として有用であると考えている。また、交通 現象(車両)に限ってではあるが、内内経路集中率による地 域内部の結合性の計量化や、道路上の断面交通量の推定 など、現実の移動現象に適用可能であることが確認され たと考える。しかしながら、ごく単純な設定のもとに議 論してみたものの、得られた理論式は多少複雑である。 特に、積分による結果が煩雑になっており、実際の交通 現象に適用するには近似化の方法を考案するなど、まだ
多くの改良を施さなければならない。また、本論では平 面上に一様ランダムに分布する経路のみを扱ったが、密 度分布を組み入れた理論の展開をはかる必要があると考 える。いずれも今後の課題としたい。

\section{注}

(1)本論においては移動経路・線分・トリップという用語は同義 とみなし、単に” 経路”之略す。

(2)円の内部に線分が含まれる場合（通過）も”交わる”と表現 する。

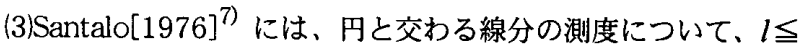
$2 R の$ との $M_{0}$ のみが定式化されている。なお、多角形と交わ る楾分の測度については導出されている。

(4) $P_{\mathrm{W} i}$ はlが所与のもとでの条件付き確率ではない。すなわち、

$$
P_{\mathrm{W} i}=\int\left\{A_{i} / R(\pi R+2 l)\right\} g(l) d l
$$

とはならないことに注意されたい。 $g(D$ は平面上に一様分布 している線分の長さの確率密度関数であって、長さの線分が 円と交わる確率を表しているわけではない。直観的にもわか るように、功長い線分ほど、円と交わる確率は $g(l) d l$ よりも 高くなるのである。この点は、以降の論証においても重要な ので、ここで、条件付き確率を用いた定式化について議論し ておく。

いま、半径Rの円を含む十分大きな領域を $D$ とし、その面積 をFとする。このとき、Dの内部に中点をもつ線分がランダム に分布しているものとする。簡単のために、線分の総数を $N$

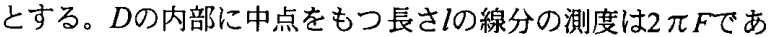
り、また、半径Rの円と交わる測度が本文(2)式で表されるか ら、円と交わる確率は

$$
2 \pi R(\pi R+2 l) / 2 \pi F=R(\pi R+2 l) / F
$$

と表される。線分の長さの確率密度関数が $g(l)$ であるから、 全体の $N$ 本の中で、長さlの線分は $N g(l) d l$ 本あることになる。 さらに、 $N g(l) d l$ 本のうち、半径 $R$ の円と交わる線分は、上式 の確率を乗じて

$$
N g(l) d l R(\pi R+2 l) / F
$$

本あることになる。したがって、N本のうち円と交わる線分 の数は、

$$
\int N g(l) d l R(\pi R+2 l) / F=N R(\pi R+2 \mu) / F
$$

となる（ $\mu$ は長さの期待值)。ここで、全事象を円と交わる線 分に限定したときの確率密度関数を $h(l)$ とすると、長さ $l$ 線 分が円と交わる確率 $h(l) d l$ は、(A2) 式を(A3) 式で除して、

$$
h(l) d l=g(l) d l(\pi R+2 l) /(\pi R+2 \mu)
$$

と求められる。上式からわかるように、期待值 $\mu$ よりも長い 線分は、円と交わる確率が $g(l) d l$ よりも大きくなるのである。

$P_{\mathrm{W} i}$ を、全事象を円と交わる線分という条件付き確率 $h(l)$ を 用いて定式化すると、本文(5)式の $P_{i}$ に(A4)式を乗じて、

$$
\begin{aligned}
P_{\mathrm{w} i} & =\int\left\{A_{i} / R(\pi R+2 l)\right\} h(l) d l \\
& =\int A_{i} g(l) d l / R(\pi R+2 \mu)
\end{aligned}
$$

となり、本文で導出した(9)式と同じ結果を得る。以上の手続 きは、本文における論証のように、経路パターン別測度 $M_{\mathrm{w}} i$ と全測度 $M_{\mathrm{w}}$ 、それぞれ $g(l) d l て ゙$ 重みづけしてから $P_{\mathrm{w} i}$ を導 出する方法と同義である。

(5)通常こういった移動距離の確率密度分布においては、期待值 よりも小さい方に密度が偏った分布形態をなすことが多い。 
そこで、ガンマ分布、対数正規分布、ワイブル分布という 3 つの典型的な確率密度関数をあてはめてみて、その中で最も 適合性のよいワイブル分布を用いることにした。

交通センサス ${ }^{9)}$ によると平均経路長 (道路距離) は $11.1 \mathrm{~km}$ である。道路ネットワーク上の2点間の実距離は、直線距離の 約1.3倍という研究報告 ${ }^{10)}$ があるので、平均経路長は直線距 離に補正すると、 $\mu=8.5 \mathrm{~km}(=11.1 / 1.3)$ となる。本文(9)、(17)、 (26)式等で示されるように、 $\mu$ の值が重要な役割を果たして おり、この值によって、パターン別の生起確率や領域内部に 含まれる線分の長さが決定づけられる。そこで、パラメータ $a, b$ につては、まず、 $\mu=8.5$ を固定してから推定した。す なわち、ワイブル分布の期待値は、

$$
\mu=b \Gamma(1 / a) / a
$$

であるから、 $b=8.5 a / \Gamma(1 / a)$ として、パラメータ $a$ を推定 するという方法を採用した。交通センサズ ${ }^{9 \prime}$ には経路長別の 頻度と平均値のみしか集計されていないので、精度の低い適 合をせざるを得ないが、パラメータの推定に際しては、ワイ ブル分布の累積分布関数

$$
F(l)=1-a l^{a-1} \exp \left[-(l / b)^{a}\right] / b^{a}
$$

と、表2に示した交通センサスのデータ（8点）から、最小二 乗法によって $a$ の值を求め、 $a=0.78 、 b=7.40$ という結果を得 た。なお、通常のように、期待值 $\mu$ を固定せずに最小二乗法 によって推定すると、 $a=0.81 、 b=7.27$ となり（この場合 $\mu=$ 8.1）、上記の方法での結果と大きな差異はみられなかった。

(6) 注 $(4)$ での説明と同様、 $E_{\mathrm{W}}(s)$ を求めるとき、(14)式に $g(D) d l$ を 乗じて、

$$
E_{\mathrm{W}}(s)=\int\left\{\pi F_{0} l /\left(\pi F_{0}+l L_{0}\right)\right\} g(l) d l
$$

とはならないことに注意されたい。全事象を凸領域と交わる 線分に限定したときの確率密度関数を $h$ ' $(I)$ とすると、

$$
h^{\prime}(D) d l=g(D) d l\left(\pi F_{0}+l L_{0}\right) /\left(\pi F_{0}+\mu L_{0}\right)
$$

となる（注(4)の(A4)式では円を対象としているが、凸領域の 場合についても同様に議論できて、結果的に上式が得られ る)。したがって、 $E_{\mathrm{W}}(s)$ を条件付き確率 $h^{\prime}(l)$ を用いて定式 化すると、本文(14)式に(A8)式を乗じて積分し、

$$
\begin{aligned}
E_{\mathrm{W}}(s) & =\int\left\{\pi F_{0} l /\left(\pi F_{0}+l L_{0}\right)\right\} h^{\prime}(l) d l \\
& =\pi \mu F_{0} /\left(\pi F_{0}+\mu L_{0}\right)
\end{aligned}
$$

となる。つまり、本文(17)式と同一の結果を得る。

(7) (20)式を用いた断面交通量の期待值の推計方法を以下に示す。 まず、対象領域の形状を凸包とし（5章参照）、(20)式にお ける $F_{0}$ と $L_{0}$ に凸包の面積 $S_{\mathrm{h}}$ と周長 $L_{\mathrm{h}}$ をあてはめる。この場合、 凸包にすると面積が增加するので、道路の総延長については、 補正のために、

$$
\gamma=S_{\mathrm{h}} / S \quad(S: \text { 実面積 })
$$

を実際の総延長 $\Lambda$ に乗じ、 $\gamma \Lambda$ として修正する必要がある。

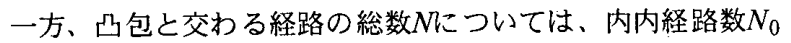
もと倍になるとみなし、

$$
N=\gamma N_{0} / P_{\text {w0 }}
$$

となる。これらの值を(20)式にあてはめると、断面流動量の 期待值 $\eta$ の推計值 $\hat{\eta}$ は次式のように求められる。

$$
\hat{\eta}=\pi \mu N_{0} S_{\mathrm{h}} / \Lambda P_{\mathrm{wo}}\left(\pi S_{\mathrm{h}}+\mu L_{\mathrm{h}}\right)
$$

5章で示すように、東京都23区において、車両の移動経路 がランダムに分布しているとみなされる行政区は数少ない。 そのなかで、練馬区については比較的ランダムに近い分布を していると推定されるので、これを例にとって、(A10)式から
断面交通量の期待値を推計してみると、道路総延長 $\Lambda=1020$ km. $\mu=11.1 \mathrm{~km}$ (この場合は道路距離)、 $S_{\mathrm{h}}, L_{\mathrm{h}}, N_{0}, P_{\mathrm{w} 0}(5$ 章表 3参照) の各值をあてはめて、 $\hat{\eta}=2411$ (台/日)と求められる。

一般の交通量 (車雨) 調査は主要な道路上において実施さ れているため、すべての道路を対象とした断面交通量の期待 值は把えきれないが、その点、この方法にはOD調査の結果を 用いて推計できるという利点がある。

(8)本来ならば、実際の行政区の形状（非凸）と円との結果を比 較しなければならない。しかし、非凸の形状と対応させるた

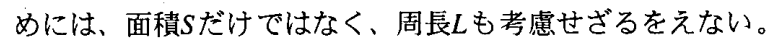
実際にいくつかの行政区でシミュレーションをしてみると、 面積が等しい場合（半径 $R 1^{=} \sqrt{S / \pi}$ ) と、周長が等しい場合(半 径 $R 2=L / \pi)$ との間に、最も適合する半径 $R(R 1 \leqq R \leqq R 2)$ が 見いだされた。しかし、各行政区ごとに面積と周長をパラメ 一タとした半径を用いるとなると煩雑さが伴う上、そもそも、 シミュレーションの值のほうを用いればよいことになってし まう。理論を適用する際の手続きは単純なほうが望ましいの で、ここでは、凸包と面積が等しい円と対応させている。

(9)行政区によっては大きな公園があったり、千代田区のように 皇居が中央部に位置している場合がある。厳密にいえば、こ ういった領域を除外したときの理論值と比較しなければなら ない。この理論值は、有孔図形（ドーナッツ型）を対象とし て、図5、6と同様な方法によって解析的に求めることができ るが、かなり煩雑になるので本論では省略している。なお、 数值的な見通しを得るために、ドーナッツ型の領域に対して、 シミュレーションによって内内比率を求めてみると、千代田 区（皇居に相当する半径 $0.7 \mathrm{~km}$ の同心円をくり抜いた形）で0. 155、渋谷区（代々木公園に相当する半径 $0.5 \mathrm{~km}$ の同心円をく り抜いた形) で0.174となった。等価円における内内比率の 理論值がそれぞれ0.148、0.168（表3）であるから、大きな 差異は見られないことが確認された。

(10) 精確を期すためには、， $\rho_{\mathrm{E}}$ は凸包の場合に換算しなければな らないが、経路数 $N_{0} 、 N_{1}$ ともに、実面積に対して同一の割合 で増加するものと仮定し、 $\rho_{\mathrm{E}}$ の值は不変であるとしている。

(11) $\mathrm{OD}$ 調查 ${ }^{11)}$ では平均トリップ長が11.3kmであり、交通センサ ス ${ }^{9}$ の結果 $(11.1 \mathrm{~km})$ より大きいが、この差は無視できるも のとし、(10)式のワイブル分布と整合性をもたせるためにも後 者の值を採用している。

\section{参考文献}

1)松浦義満,沼田道代(1987): 都心周辺部における通勤目的の内内交通 量の推計方法に関する考察,土木学会論文集,383号/IV7,pp.45-53.

2)腰塚武志(1992) : 都市域の流動に関する理論的考察, 都市計画論文集No.27,日本都市計画学会,pp343-348.

3)及川清昭(1993) : 平面上の流動量に関する計量幾何学的モデル, 日本建築学会関東支部研究報告集、pp385-388.

4)及川清昭(1993)：都市空間における流動量の幾何確率的考察, 日本建築学会大会学術講演梗概集,pp751-752.

5)栗田治(1993) : 移動量の減衰関数に基づいた領域間距離の近似公式 都市計画論文集No.28,日本都市計画学会,pp391-396.

6)及川清昭(1994):都市空間に抠る経路と流動量に関する計量幾何学 的分析,日本建築学会大会学術講演梗概集,pp505-506.

7)L.A.Santalo(1976) : Integral Geometry and Geometric Probability, Addison-Wesley Publishing Company.

8)腰塚武志(1976): 積分幾何学について(1)〜(4),オペレーションズリ サーチ,vol.21,pp.524-529,591-596,654-659,711-717.

9)建設省道路局(1991):平成2年道路交通センサス,自動車起終点調查集計表. 10)腰塚武志, 小林純一(1983) : 道路距離と直線距離, 学術研究発表会論 文集,都市計画別冊,No.18,日本都市計画学会,pp43-48.

11)東京都建設局道路建設部(1987): 東京都の自動車交通の実態.

(1996年. 2 月 10 日原稿受理, 1996年 6 月 20 日採用決定) 